\title{
Financialisation: continuity and change- introduction to the special issue
}

\section{Engelbert Stockhammer ${ }^{1} \cdot$ Stefano Sgambati $^{2} \cdot$ Anastasia Nesvetailova $^{3}$}

(C) European Association for Evolutionary Political Economy 2021

The notion of financialisation has been around for quite some time. Since its early formulations (e.g. Arrighi 1994; Sweezy 1997; Froud et al 2000; Stockhammer 2004; Epstein 2005; Krippner 2005), a great deal of studies have been published with a view to making sense of the many issues surrounding this topic. Admittedly, a lot of ground has been covered. We have learned that financialisation is about the 'macro', the institutional, structural and systemic processes that are associated with it, as well as the 'micro', the agencies that are affected by and shape these historical processes through financial practices and innovations that transform not only economies and societies, but also cultures, subjectivities, geographies and more (van der Zwan 2014). Today, the field of financialisation studies cuts across several disciplines and indeed challenges many disciplinary boundaries (Ertürk et al 2008, Mader et al. 2020). Therefore we should not be surprised that the concept of financialisation remains disputed and that perhaps no final agreement will ever be reached on the nature, history and significance of its phenomenon. Opinions will continue to range from viewing financialisation as a ubiquitous force, synonymous with deeply fractured capitalism, to something very specific, linked, but not confined to, a central role of the financial system and risk calculations in everyday life. At this point, a devil's advocate might ask: whither financialisation? This special issue is organised around the themes of continuity and change in financialisation, and it showcases new research on the frontiers of financialisation and the broader debates surrounding its evolution. It also illustrates the vitality of the debate and the usefulness of concept. In this introduction, we highlight some of the most interesting findings from this special issue, contextualise their contribution and comment on the state of the financialisation debate - its shifting boundaries, (in)coherencies and (dis)continuities in the twenty-first century.

Engelbert Stockhammer

engelbert.stockhammer@kcl.ac.uk

1 King's College London, London, UK

2 City, University of London, London, UK

3 UNCTAD, Geneva, Switzerland 


\section{Shifting boundaries of finance}

There are different ways to group the approaches within the financialisation debate. First, after about two decades of the evolution of the concept, one can delineate two approaches to the phenomenon of financialisation. One the one hand, there are historical accounts of the rise of financialisation or finance-led capitalism (e.g. Arrighi 1994; Toporowski 2020); on the other, there are more specific, contemporary studies of the sociology and economics of this process (more on this in the next section). The key question for the historical studies of financialisation and its antecedents concerns the effects of the growing power of the financial industry over the rest of the economy, society and the political realm. The key question for the sociological accounts of financialisation is how, and to what effects, various human habitats are absorbed by the financial dynamics, thereby becoming new elements of the financial system (Nesvetailova 2013). And while these two traditions continue to debate the origins and drivers of financialisation, both tend to agree that the process of financialisation has become an important determinant of global capitalism in the twenty-first century because it erodes the boundaries that defined the structure of the economy before the ascent of financialisation or charts new lines of division and power relationships because financialisation not only transforms the socio-economic system, but also enlarges it, by involving new entities and processes into its ecology.

It is the very theme of boundaries - structural and created, political and economic - that runs through the articles by Giselle Datz (2021), Lysandrou and Ranjbaran (2021) and Leaver and Martin (2021) in this special issue. All three papers continue the epistemological discussion of financialisation while studying its manifestations in three different, but equally crucial, political-economic contexts: the realm of state sovereignty (Datz), the realm of international markets (Lysandrou and Ranjbaran) and the realm of the corporation (Leaver and Martin). In so doing, they advance both approaches on financialisation, because they each study the mechanisms of power and control stemming from global finance. At the same time, they each also deepen our knowledge of the varieties of financialisation as they examine its specific legal and political-economic mechanisms in depth.

Using the case of Argentina, Giselle Datz (2021) explores the political impact of the legal power of debt contract. Sovereign debtors engaging in global financial markets become subjected, through the legal anchoring of foreign sovereign bond contracts, to law of particular jurisdictions. As she argues, one major consequence of this is that global efforts to reform debt governance around market-based parameters have been led, and contractual changes sparked by, outlier cases of protracted litigation or recent instability in debt exchanges. Traditional boundaries of both inter-state relationships have been re-charted by the deepening of financial contracts and calculations. Lysandrou and Ranjbaran (2021) analyse the destructive power of financialisation, by focusing on the functionality of ever-expanding financial market and its impact on the long-standing core-periphery divide between the advanced and the emerging markets economies, which is being reinforced through financial and monetary mechanisms in the wake of the pandemic. Leaver and Martin (2021) examine the complex normative aspects of the socio-legal framing of the contemporary firm, 
examination the role of financialisation in reshaping the conventional notions and boundaries of the corporation.

\section{An incoherent concept or different sectoral effects?}

Financialisation is shifting the boundaries of states, markets and corporations, but is also shifting its own boundaries — as an object of investigation — and eluding attempts to define once and for all its semantic domain. Admittedly, a frequent criticism of the financialisation debate is that it lacks an analytically sharp definition of financialisation and an agreed set of core propositions. Different authors define the term differently and this inevitably engenders ambiguities, if not incoherencies. While most authors endorse Epstein's (2005) general definition of the rising influence of financial actors or motives, there is little operational agreement on the mechanisms or the effects. Part of this apparent incoherence is due to the organisation of research. Financialisation is after all a multidisciplinary conversation, and one should not be surprised to find that works from different fields and disciplinary backgrounds often yield conflicting interpretations. Part of the elusiveness and even indeterminacy that financialisation is vested with is grounded in seemingly contradictory reality. Financialisation escapes sharp definition because its material object varies and, to some extent, the incoherencies in the use of the term reflect the variety of effects that financialisation has on different actors and sectors. This can be illustrated with respect to the question of the macroeconomic effects of financialisation. Consider the standard macroeconomic sectors: businesses, households and finance. Around each of these sectors, distinct streams of the financialisation debate have developed.

A first important debate on financialisation was the discussion of the impact on non-financial businesses, often under the heading of shareholder value orientation (Lazonick and O'Sullivan 2000; Stockhammer 2004; Orhangazi 2008; Hein and van Treeck 2010; Lazonick 2014; Davis 2017; Tori and Onaran 2018; Rabinovich 2019). The objectives of firms and the constraints that they are facing have changed with rising shareholder voice and the increase in hostile takeovers, corporate restructuring, asset stripping, etc. There has been some debate on whether this was due to constraints on firms imposed by financial players (i.e. management as victim) or whether this should be thought of as transformation of firms themselves, with management pursuing these changes (and along the way gaining share options), but the main effect on firm's investment dynamics (lower physical investment, more dividend payments and share buybacks) was agreed, as was the impact on labour (wages squeezed due to higher financial payments). In this special issue, Davis and MCormack (2021) and Auvray et al (2021) continue this debate. Davis and MCormack are proposing a Sweezy-inspired interpretation of corporate financialisation, which suggests that financialisation was particularly pronounced in sectors with weak real growth prospects. Auvray et al. highlight differences in the early and later phases of corporate financialisation, with the former dominated by high 
interest rates and the latter with growing importance of global value chains and intellectual property rights.

A second crucial debate, chronologically subsequent to the shareholder value debate, was that on the financialisation of households (e.g. Watson 2010). Changes in the relationship between households and finance entailed a shift from pay-as-yougo pension schemes to capital-based pension schemes and the emergence of investor identities (Langley 2004), but macroeconomically, the most important change surely was the assetisation of housing. Banks discovered mortgages as a lucrative and supposedly safe asset class, and real estate prices and household debt grew sharply. House price inflation and the use of equity release mortgages led to real effects via consumption expenditures and residential investment booms. This very phenomenon was also subject to a more technical literature often emanating from central banks and applied mainstream research institutions under the heading of wealth effects (e.g. Case et al 2005; Aron et al 2012; on the post-Keynesian side: Stockhammer and Wildauer 2016). Thus, the growth effects of household financialisation were positive prior to the Global Financial Crisis (GFC), giving rise to what has often been called finance-led or debt-driven growth models (Hein 2012; Lavoie and Stockhammer 2013). Much of the financialisation literature on households, with its strong cultural and constructivist twist, did not make full use of that more economics research, and our special issue has little on financialisation of household and housing, with the main exception being Fuller (2021) who emphasises a shift from homeownership finance to financing rental housing since the GFC (more on this in the next section).

Third, the changes within the financial sector in the last decades have been enormous with financial globalisation, securitization and the rise a shadow banking sector. Risking a brutal simplification, we might summarise the main impact of financialisation as assetisation (securitisation) on the one hand and a shift to housing finance on the other hand. These have substantial macroeconomic effects, the short of which is that that they give rise to financial cycles. Assetisation, which in many cases came with securitisation, means turning illiquid assets (e.g. mortgage loans), future income streams or possible future transactions into tradeable assets, which are then daily priced on financial markets. For financial institutions, assetisation meant a shift towards market-based banking and fee-generating incomes (Hardie et al 2013; Knafo 2021). In practice, often assets and liabilities rise on the balance sheets of financial, but also non-financial institutions (with the hope that the value of assets rising faster). This parallel rise of assets and liabilities is only attractive if the values of assets and liabilities exhibit different dynamics. There are different ways that this parallel rise of assets and liabilities can occur. Hedging, i.e. buying additional assets that promise an insurance against adverse outcomes, may give rise to it, but so does speculation. Speculation, in our context, means buying financial assets, usually financed by issuing debt, in the expectation of a rise in asset's price. From a Minskyan perspective, this increases financial fragility as gross debt-to-income ratios rise, and debt has to be serviced from current income (Minsky 2016; Ryoo 2016). Thus balance sheets become more sensitive to changes in asset valuations or current income. But the fact that assets are traded on financial markets itself has the potential to create instability, or more precisely, endogenous boom-bust cycles. 
There is a substantial literature that demonstrates the emergence of financial asset price cycles from the interaction of extrapolative and fundamentalist trading strategies (Beja and Goldman 1980; de Grauwe 2012; in the context of real estate markets Dieci and Westerhoff 2012). The starting point of these models is heterogeneity of agents, more precisely heterogeneity of the way that they form expectations for future prices. A fundamentalist heuristic expects prices to be anchored in some fundamental value; momentum traders extrapolate price movements of the recent past. While actual financial actors will have more complex expectations, the interaction of these two basic strategies is sufficient to generate boom-bust cycles.

The main implication of this for the financialisation debate is that one should conceive of the financialisation process as one that unleashes inherently cyclical (as opposed to linear) dynamics. On the macro level this finds its expression in the return of the financial cycle. While financial cycles and banking crises were muted in the (Bretton Woods) postwar era, since the 1980s, the world has witnessed a series of financial crises (Jordá et al. 2013, Borio 2014, Aikman et al. 2015). Macroeconomically, this means that the 'finance-dominated accumulation regime' will have financial booms as well as extended periods of finance-led stagnation where various units try to deleverage. From this perspective, the 'secular stagnation' since the GFC is not surprising and the downturn of the financial cycle should not be confused with a genuine de-financialisation.

Finally, we should not expect the real-world financial cycle to be symmetrical. Simple stylized models of the endogenous financial cycles are constructed to highlight mechanisms that generate upswings as well as downswings (i.e. there is a symmetry). In actual political economies, during a crisis, there will be increasing political pressure to act whether in the form of Keynesian expansion, protectionism or intensified distributional conflict. The resulting policy reactions will be highly contingent, and financialisation theories have limited capacity to explain these; they will depend on the specific political constellations of a country, on the constraints it faces, etc., but the fact that the financial cycles unleashed by financialisation will lead to crises that will increase demand for economic policy reaction is in itself significant. That's because economic policy matters. The IMF famously admitted that in recessions, fiscal multipliers are much larger than conventional macroeconomic models allow for Blanchard and Leigh (2013) and differences in fiscal policy since the GFC go a long way in explaining differences in cross country economic performance (Kohler and Stockhammer 2021). In our special issue, Hein and Martschin (2021) analyse how economic policies strategies, which they define broadly to include fiscal, monetary and wage policy, have differed across countries in response to crisis and how that has impacted growth. They argue that different policy stances have had a major impact on the growth performance of countries since the GFC.

\section{Financialisation in the twenty-first century: continuity and change}

While financialisation displays a cyclical nature, marked by the rhythms of booms and busts, it is nevertheless a historical process and, as such, bears elements of radical change. Many of these changes are tied to the GFC and the ensuing period of 
secular stagnation and low interest rates, but some begin earlier. Looking at the evolution of non-financial corporations over the past 40 years, in this issue, Auvray et al. (2021) note how financialisation in the twenty-first century continues to be marked by a persistent decline in fixed capital formation, or else 'non-financial' investments, as well as by an increase in the globalisation of trade and an unwavering shareholder value orientation in corporate management. At the same time, they point to some significant discontinuities. While financialisation in the 1980s-1990s was characterised by high interest rates and high net interest payments for non-financial corporations, things have drastically changed in the 2000s-2010s as real interest rates have plunged, reaching below zero in some years. Arguably, the new monetary conditions of overabundant and cheap liquidity have further entrenched practices of financialised corporate management in the twenty-first century, now grafted onto a much thicker layer of corporate debt. Corporations have made far greater use of capital market financing for a variety of purposes. Some have leveraged their balance sheets to acquire competitors with a view to both increasing their monopoly power and raising earnings per share. Others have issued debt for the opposite reasons, namely, to make their balance sheets less attractive to leveraged buyouts. Virtually all corporations have increased their reliance on debt to finance stock repurchases programmes ('buybacks') that boost shareholder returns and at once enable tax avoidance (interest payments are often tax deductible while dividends are not). As Knafo and Dutta (2019) recently pointed out, corporate leverage is not a new phenomenon (see also Toporowski 2020); it was first pioneered by US conglomerates in the 1960s, and it has since become the bread and butter of the shareholder revolution. Having less cash and more debt was the credo of the 'barbarians at the gates' of corporate America in the 1980s. ${ }^{1}$ However, the shareholder revolution started a decade earlier, in the 1970s, when monetary conditions (very low or negative real interest rates) created a strong institutional incentive for corporate takeovers and management buyouts of undervalued companies, including through the issuance of high-yield junk bonds. The junk bond industry would then boom in the 1980s, a contributing factor being again the steady decline in interest rates that followed the 1979-1982 monetarist phase. But in the 1980s, it was mostly to keep the barbarians at bay that US corporate managers devised poison pills, golden parachutes and the infamous stock buybacks (illegal before 1982 in the USA). Alas, these new corporate strategies inadvertently accelerated the financialisation of corporate management. By the 1990s, corporate raids and takeovers became more difficult to execute because by then the boards of directors of many corporations had been barbarised from within by a new type of activist shareholders - usually proxies of hedge funds - who were uniquely concerned with making capital gains and, to that purpose, put pressure on management to maximise shareholder value. The financialisation of non-financial corporations would then shift gears and reach new heights in the 2000s. At the turn of the century — and in particular following the dot.com crash

\footnotetext{
${ }^{1}$ Barbarians at the Gate: the Fall of RJR Nabisco was a timely book by investigative journalists Bryan Burrough and John Helyar (1989) on the leveraged buyout of RJR Nabisco and a window on the financial practices that revolutionised American corporate management in the 1980s.
} 
— the competitive pressures of the 1980s were giving way to a new situation characterised by growing monopolisation and concentration of corporate ownership, as evidenced by Auvray et al. (2021). The sharp decline in interest rates of the 2000s served as a catalyst for an intensification of acquisitions, buyouts and buybacks that were increasingly financed through bond issuance. The capital market financing of corporate leverage has been a boon for shareholders. As leverage ratios started to grow, so did net payouts to shareholders. Meanwhile, net interest payments declined (Auvray et al 2021; see also Baines and Hager 2021).

The global recessionary environment of the immediate post-2008 period has only reinforced the positive feedback loop between corporate leverage and shareholder value maximisation. In this issue, Mantoan et al. (2021) offer evidence of this as they look at the behaviour of Brazilian non-financial corporations in the 2010s. One main finding of their study is that under such circumstances, low interest rates can hinder the resumption of investments and fixed capital formation, as non-financial corporations are incentivised to venture into the territories of speculative and Ponzi debt financing. Ironically, when the economy is in a downturn and expectations are low, cheap credit might as well end up favouring a generalised weakening of corporate balance sheets, as it enables highly indebted firms to stay afloat. Thus low interest rates and quantitative easing have been effective in preventing a full blown depression, but they are insufficient to invigorate growth in an economy with a severe debt overhang (which is essentially the Keynesian explanation of secular stagnation). To some extent, the Brazilian experience is indicative of contemporary global trends. In a recent study published by the Bank for International Settlements, Banerjee and Hoffman (2018) estimate that in 2016 some 12 percent of listed nonfinancial corporations in fourteen advanced economies were 'zombie companies' that issued below-investment grade bonds simply to finance their current liabilities (see also Hallak et al. 2018). Zombie companies are one of the unintended consequences of rock-bottom interest rates and only the tip of the iceberg of corporate leverage. As of 2019, half of the investment-grade bonds issued by corporations at the global level are BBB-grade, that is, just above junk level. Unsurprisingly, as the pandemic hit in 2020, capital markets immediately experienced a dramatic surge in 'fallen angels', prompting central banks to loosen their collateral requirements to accept below-investment grade bonds and to establish new bailout facilities to keep the corporate zombies (more debt than) alive. Leverage, monopolisation and zombification - these are some of the distinctive features of a corporate financialisation that, under current monetary conditions, have paradoxically become more resilient despite (or perhaps by virtue of) its growing reliance on liquid financial markets.

The twenty-first century also marks a watershed for the financialisation of housing. Until the GFC, households had been drawn into debt finance mainly as homeowners, enticed by the promise of a democratisation of capital gains in the housing market. By the 1990s, it became common to think of housing as an asset that was bound to appreciate over time and therefore ensure a substantial equity buildup that could be extracted at some point, if needed. The making of an 'asset economy' was promoted by a widespread shift in fiscal regimes that started favouring household leverage and capital gains in the housing market (Adkins et al. 2020). For many, homeownership became a debt-based safety net, indeed an ATM for equity 
extraction on demand. For others, especially starting from the 2000s, when interest rates went down, getting a mortgage represented a unique investment opportunity to flip properties and make capital gains or to invest for non-occupancy purposes with a view to extracting rent from tenants (Goldstein 2018). This chapter in the financialisation of housing has come to a close with the GFC, the turning point of the financial cycle, and things have taken a different direction since then. As Fuller (2021) points out (in this issue), the financialisation of housing in the twenty-first century is in many ways reversing the late twentieth century trend towards democratising capital gains and diffusing homeownership, veering instead towards the assetisation of rented properties and a greater concentration of corporate power in the housing market. The key drivers of this process are real estate investment trusts (REITs) and alike financial firms (in his article, Fuller also discusses real estate operating companies, or REOCs). REITs are not a recent phenomenon. They have existed since the mid-twentieth century. However, while traditionally they used to target commercial property, starting from the 2000s, REITs also started to invest in residential property. The 2007-2008 crisis served as a major catalyst in this respect. As the US housing market started to crash in 2007, many traditional real estate investment firms that had been engaging in house flipping were forced to liquidate their property investments. REITs and REOCs swiftly moved in to acquire residential properties on the cheap. Since entering the scene in the 2000s, REITs have become some of the largest landlords in the world. As Fuller (2021) reports, at present, the largest 25 REITs in the USA collectively own about 300,000 homes, which they rent out to tenants from different socio-economic groups. On the one hand, the largest, high-end REITs focus on high-value properties in the East and West coasts, targeting upper-to-middle income professionals; meanwhile, the smaller REITs focus on lower-cost areas that are relatively more affordable. In both cases, REITs constitute a major vehicle of urban gentrification. Fuller (2021) explains that residential REITs are pursuing a less speculative and risky type of business compared to traditional, twentieth-century real estate firms: instead of chasing short-term capital gains, they seek income-like returns on longer-term investments. The recent case of Evergrande - the Chinese real estate investment behemoth with about 2 trillion yuan $(\$ 310$ billion) of outstanding debts and shareholders' equity only amounting to $6.38 \%$ of total assets ${ }^{2}$ - appears to be an outlier in this respect, as residential REITs tend to rely on a balanced mix of debt and equity financing for their property investments. This said, residential REITs only constitute a fraction of the REIT universe, which comprises healthcare, retail, office, mall and commercial REITs. Many of these real estate groups fall under the category of speculative and Ponzi financing units. Consider, for instance, Simon Property Group and American Tower, two of the largest US commercial REITs. Like Evergrande, their shareholders' equity only amounts to a fraction (around 8\%) of their total assets - their leverage ratios resembling those of large hedge funds and investment banks (on balance sheet). As the pandemic hit, both real estate groups experienced a growth of assets and profits to the detriment of

\footnotetext{
${ }^{2}$ Evergrande's balance sheet can be found at https://www.marketwatch.com/investing/stock/3333/finan cials/balance-sheet? countrycode $=\mathrm{hk}$
} 
many smaller REITs that had invested in malls and brick-and-mortar shops and were dragged to bankruptcy.

In many ways, the pandemic served as a litmus test for financialisation. If someone doubted how much more debt could financial markets absorb before imploding, they now have the answer: the sky is the limit. As Lysandrou and Ranjbaran (2021) remind us in this issue, financial markets thrive on debt - that is, as long as monetary authorities and the governments behind them are ready to backstop its market-makers. As indebtedness across sectors (including the issuance of equity instruments) grows at every quarter, so does the volume of capital and money market trading - keeping broker-dealer banks and other market-makers busy extracting trading fees and commissions, but also reassuring asset managers about the liquidity of their portfolios. For Lysandrou and Ranjbaran (2021), the pandemic has reinforced the functionality of financialisation, as a regime of 'permanent bond borrowing' and 'constant bond rollover', and the scale of its operations, which have not been fundamentally disrupted but instead have been expanded and magnified. Their analysis focuses in particular on the issue of government borrowing. Because of the pandemic, government debt in the OECD area has increased by another $\$ 5.7$ trillion in 2020 - a figure that is $\$ 3.5$ trillion higher than pre-COVID estimates (Lysandrou and Ranjbaran 2021). This surge in government bond issuance has taken place once more in a context of zero interest rates, which has been great for both the indebted governments of the Global North and the global investors looking for safe assets amid a global economic recession. For these, government bonds might have low or negative yield, but for the same reason, they also trade at a premium, at par or quasi par, depending on their maturity date and, of course, their risk profile. Hence, for a large share of institutional investors, short-term bonds (up to 3- or even 5-year maturity date) have become a money-like store of value that trades at quasi-par and therefore satisfies their demand for safety and liquidity. Government bonds have always been considered a safe asset. However, in the past, they were sought after as a fixedincome investment in the capital market because of the interest they offered. Now, under the twenty-first-century conditions of zero interest rates, government bonds have become the most precious collateral asset in the money market, which is used to back all sorts of money market instruments that are sought after by global investors, not when they want to actually invest (with a view to making a return), but when they need to save (Ricks 2016; Sgambati 2019). This is especially true for US treasury securities: they might not trade at a premium the way German bonds do, but they are nevertheless at the heart of the largest and deepest reservoir of moneylike instruments in the world - the US repo market (Gabor 2016). Alas, following Lysandrou and Ranjbaran's argument, this creates a vicious circle: as global investors seek US treasury securities for their liquidity and the store of value function that they provide, interest rates in the USA are further depressed and kept at rock bottom level — making it altogether cheaper for distressed borrowers worldwide to take on more debt by tapping on the US money market.

Among these distressed borrowers are also commercial REITs, zombie companies and governments from the Global South. Access to USD-denominated credit, however, is not universally cheap, even when interest rates are low or negative: for the USA and, to a smaller extent, for other advanced market economies, bond 
issuance at zero or negative interest rates offers fiscal relief, and, in some cases (when bond yields are negative), it even functions as a tax on bondholders (which include pension funds, mutual funds and insurance companies). By contrast, for emerging market economies, borrowing continues to have a real cost, as their debts are not deemed to be as safe and ought to offer a higher yield to appeal global investors - in this case, not because they want to save (store) their cash (value), but because they are looking for fixed income opportunities.

\section{Conclusion}

The discontinuities and changes that have marked these first two decades of the twenty-first century invite a reflection on the status of financialisation as a historical phenomenon. Three main schools of thought stand out in this respect: the Sweezyan, the Arrighian and the Minskyan. Both Sweezy (1997) and Arrighi (1994) have a production-based understanding of the causes of financialisation. For Sweezy (1997), financialisation is the consequence of an exhaustion of 'real' growth potential, therefore a shift towards financial activities in search for surplus generation. While this view allows for financial bubbles, it ultimately stresses the deep contradictions of the processes underlying financialisation and points to seemingly unescapable tendencies that have no historical precedent (e.g. the secular stagnation thesis). Arrighi (1994) similarly understands financialisation as the last refuge of a capitalist class whose productive system is no longer able to generate growth cum profits; however, he proposes a longue-duree view of secular hegemonic cycles where financialisation comes as the autumn of a historical-specific regime of accumulation, when the leading power loses its productive edge and moves to financial activities. In this case, the current secular stagnation is not a terminal (seemingly unsurmountable) crisis, but one that will involve a rather chaotic and conflict-ridden reconfiguration of the geography of power and the start of a new season for capital with a new hegemon emerging. The last school of thought is inspired by Minsky who, notably, did not have a theory of financialisation as a historical phenomenon. For Minsky, financial expansion does not (logically and/or historically) follow material expansion but always constitutes a necessary feature of expansion process. While the debt financing of the economy (short: increasing leverage) helps to fuel the boom in the short run, ultimately a high leverage is destabilising and inexorably leads to crisis. While the financial sector can be more or less tightly regulated, capitalism is always financialised. Less regulated regimes could be call more 'financialised'), but financialisation is intrinsically cyclical, and thus the current crisis is one that will last longer than a regular recess and will only be resolved when households and firms manage to reduce their debt burdens. Crucially, how long that will take, and how deep the stagnation will be, will depend on the economic policy response.

This special issue offers a selection of contemporary research on financialisation. As such, it highlights continuity and change in financialisation. The continuity is in the strong influence of finance on, and often power over, other economic sectors and social actors. These impacts, in particular the macroeconomic effects, differ by sector, and they do set motion or amplify financial cycles, which in the GFC 
demonstrates far reaching effects. The change involves continuous financial innovation, but already for the post-1980 period that is usually the focus of financialisation research gave rise to distinct phases of financialisation: a shift from the high interestlow growth 1980s centred on corporate financialisation; to a phase (mid-1990s to the GFC) where capital gains on financial assets have taken over from high interest rates as the indication of financial power, where high growth was generated by a housing boom that fed economic growth; and to a period since the GFC, where low interest rate combine with low growth in a debt overhang economy.

The contributions to this issue have also documented the shifting boundaries of finance. The nature of the firm but also state capabilities is increasingly shaped by financial processes. In parallel with the continuous innovation of financial products, we observe novel mechanisms of financial extraction. In this issue, this was documented around intellectual property rights and the shift of housing-related activities from those surrounding home ownership to rentals. There are more areas of that, such as the financialisation of commodities and food. Financialisation keeps illustrating the link between everyday life (housing, food) and the high spheres of finance and financial engineering (e.g. Clapp and Isakson 2018). In other words, financialisation is part of the marketisation of realms that were previously not or less commodified. That process produces its own Polanyian counter-movements, such as the recent successful referendum about the socialisation of housing corporations in Berlin (Vasudevan 2021). It has its internal contradiction as analysed by Minskyan theory of financial instability and illustrated by the GFC. It may also run up against the physical limit of the earth's biosphere. One key question for the future, but not tackled in this special issue, is to what extent financialisation will enable or disable the decarbonisation of economic processes. What we have not seen so far is a definancialisation that would shift power away from finance and the superrich.

\section{References}

Adkins L, Cooper M, Konings M (2020) The asset economy. Polity Press, Cambridge

Aikman D, Haldane AG, Nelson B (2015) Curbing the credit cycle. Econ J 125:1072-1109

Aron J, Duca J, Muellbauer J, Kurata K, Murphy A (2012) Credit, housing collateral, and consumption: evidence from Japan, the UK and the US. Rev Income Wealth 58(3):397-423

Arrighi G (1994) The long twentieth century. Verso, London

Auvray T, Durand C, Rabinovich J, Rikap C (2021) Corporate financialization's conservation and transformation: from Mark I to Mark II. Rev Evol Polit Econ

Baines J, Hager S (2021) The great debt divergence and its implications for the covid-19 crisis: mapping corporate leverage as power. New Polit Econ. https://doi.org/10.1080/13563467.2020.1865900

Banerjee R, Hoffman B (2018) The rise of zombie firms: causes and consequences. BIS Q Rev September, 67-78

Beja A, Goldman MB (1980) On the dynamic behaviour of prices in disequilibrium. J Financ 25:235-248

Blanchard O, Leigh D (2013) Growth forecast errors and fiscal multipliers, International Monetary Fund Working Paper WP13/1

Borio C (2014) The financial cycle and macroeconomics: what have we learnt? J Bank Finance 45:182-198

Burrough B, Helyar J (1989) Barbarians at the gate: the fall of RJR Nabisco. Harper and Row, New York

Case K, Quigley J, Shiller R (2005) Comparing wealth effects: the stock market versus the housing market. Adv Macroecon 5(1):1235-1235 
Clapp J, Isakson R (2018) Risky returns: the implications of financialization in the food system. Dev Chang 49(2):437-460

Davis L (2017) Financialization and investment: a survey of the empirical literature. J Econ Surv 31(5):1332-1358

Davis L, McCormack S (2021) Industrial stagnation and the financialization of nonfinancial corporations. Rev Evol Polit Econ this issue

De Grauwe P (2012) Booms and busts in economic activity: a behavioral explanation. J Econ Behav Organ 83:484-501

Dieci R, Westerhoff F (2012) A simple model of a speculative housing market. J Evol Econ 22:303-329

Epstein G (2005) Introduction: financialization and the world economy. In: Epstein G (ed) 2005: Financialization and the world economy. Edward Elgar, Cheltenham, pp 3-18

Ertürk I, Froud J, Johal S, Leaver A, Williams K (2008) Financialization at work. Routledge, Key Texts and Commentary

Froud J, Haslam C, Johal S, Williams K (2000) Shareholder value and financialization: consultancy promises, management moves. Econ Soc 29(1):80-110

Fuller G (2021) The financialization of rented homes: continuity and change in housing financialization. Rev Evol Polit Econ this issue

Gabor D (2016) The (impossible) repo trinity: the political economy of repo markets. Rev Int Polit Econ 23(6):967-1000

Giselle Datz G (2021) Financialization and sovereign debt as private contract. Review of Evolutionary Political Economy (this issue)

Goldstein A (2018) The social ecology of speculation: community organization and non-occupancy investment in the U.S. housing bubble. Am Sociol Rev 83(6):1108-1143

Hallak I, Harasztosi P, Schish S (2018) Fear the walking dead? Incidence and effects of zombie firms in Europe. Publications Office of the European Union, Luxembourg

Hardie I, Howarth D, Maxfield S, Verdun A (2013) Banks and the false dichotomy in thecomparative political economy of finance. World Polit 65(04):691-728

Hein E (2012) The macroeconomics of finance-dominated capitalism - and its crisis. Edward Elgar, Cheltenham

Hein E, van Treeck T (2010) Financialisation and rising shareholder power in Kaleckian/post-Kaleckian models of distribution and growth. Rev Polit Econ 22(2):205-233

Hein E, Martschin J (2021) Demand and growth regimes in finance-dominated capitalism and the role of the macroeconomic policy regime: a post-Keynesian comparative study on France, Germany, Italy and Spain before and after the Great Financial Crisis and the Great Recession. Rev Evol Polit Econ

Jordá O, Schularick M, Taylor A (2013) When credit bites back: leverage, business cycles and crises. J Money Credit Bank 45(2):3-28

Knafo S (2021) The power of finance in the age of market based banking. New Polit Econ. https://doi.org/ $10.1080 / 13563467.2021 .1910646$

Knafo S, Dutta S (2019) The myth of the shareholder revolution and the financialization of the firm. Rev Int Polit Econ 27(3):476-499

Kohler K, Stockhammer E (2021) Growing differently? Financial cycles, austerity and competitiveness since the global financial crisis. Rev Int Polit Econ, forthcoming.https://doi.org/10.1080/09692290. 2021.1899035

Krippner G (2005) The financialization of the American economy. Soc Econ Rev 3:173-208

Langley P (2004) In the eye of the "perfect storm": the final salary pensions crisis and the financialization of Anglo-American capitalism. New Political Economy 9(4):539-558

Lavoie M, Stockhammer E (2013) Wage-led growth: concept, theories and policies. In: Lavoie M, Stockhammer E (eds) Wage-led growth. An equitable strategy for economic recovery. Palgrave Macmillan, London, pp 13-39

Lazonick W (2014) Profits without prosperity. Harv Bus Rev 47-56

Lazonick W, O’Sullivan M (2000) Maximizing shareholder value: a new ideology for corporate governance. Econ Soc 29(1):13-35

Leaver A, Martin K (2021) 'Dams and flows': sketching a relational theory of the financialized firm review of evolutionary political economy (this issue)

Lysandrou, P, Ranjbaran T (2021) Financialisation reinforced: the enduring legacy of the covid pandemic. Rev Evol Polit Econ this issue

Mader P, van der Zwan N, Mertens D (eds) (2020) International Handbook of Financialisation. Routledge 
Mantoan E, Centeno V, Feijo C (2021) Why has the Brazilian economy stagnated in the 2010s? A Minskyan analysis of the behavior of non-financial companies in a financialized economy. Rev Evol Polit Econ this issue

Minsky H P (2016) The financial instability hypothesis: a restatement. In: Can 'it' happen again? Essays on instability and finance. Routledge, Oxon

Nesvetailova A (2013) Money and finance in a globalised economy. In: Palan R (ed) Global political economy, contemporary theories. Routledge, London

Orhangazi Ö (2008) Financialisation and capital accumulation in the non-financial corporate sector: a theoretical and empirical investigation on the US economy: 1973-2003. Camb J Econ 32:863-886

Rabinovich J (2019) The financialization of the non-financial corporation. A critique to the financial turn of accumulation hypothesis. Metroeconomica 70(4):738-775

Ricks M (2016) The money problem. Rethinking financial regulation. University of Chicago Press, Chicago

Ryoo S (2016) Household debt and housing bubbles: a Minskian approach to boom-bust cycles. J Evol Econ 26(5):971-1006

Stockhammer E (2004) Financialisation and the slowdown of accumulation. Camb J Econ 28:5

Stockhammer E, Wildauer R (2016) Debt-driven growth? Wealth, distribution and demand in OECD countries. Camb J Econ 40(6):1609-1634

Sgambati S (2019) The art of leverage: a study of bank power, money-making and debt finance. Rev Int Polit Econ 26(2):287-312

Sweezy PM (1997) More (or less) on globalization. Monthly Review 49, no. 4. https://monthlyreview. org/1997/09/01/more-or-less-on-globalization/. Accessed 3/11/2021

Toporowski J (2020) Financialisation and the periodisation of capitalism: appearances and processes. Review of Evolutionary Political Economy 1(2):149-160

Tori D, Onaran O (2018) The effect of financialization and financial development on investment. Evidence from firm-level data for Europe. Camb J Econ 42(5):1393-1416

van der Zwan N (2014) Making sense of financialisation. Soc Econ Rev 12:99-129

Vasudevan A (2021) Berlin's vote to take properties from big landlords could be a watershed moment. Guardian 29 Sept. 2021. https:/www.theguardian.com/commentisfree/2021/sep/29/berlin-votelandlords-referendum-corporate. Accessed 3/11/2021

Watson M (2010) House price Keynesianism and the contradictions of the modern investor subject. Hous Stud 25(3):413-426 